\title{
RESEARCH
}

Open Access

\section{Alpha-synuclein activates the classical complement pathway and mediates complement-dependent cell toxicity}

Emil Gregersen ${ }^{1,2}$, Cristine Betzer ${ }^{1,2}$, Woojin S. Kim³, Gergo Kovacs ${ }^{1,2}$, Lasse Reimer ${ }^{1,2}$, Glenda M. Halliday ${ }^{3}$, Steffen Thiel ${ }^{2}$ and Poul Henning Jensen ${ }^{1,2^{*}}$ (D)

\begin{abstract}
Background: Synucleinopathies are characterized by neurodegeneration and deposition of the presynaptic protein a-synuclein in pathological protein inclusions. Growing evidence suggests the complement system not only has physiological functions in the central nervous system, but also is involved in mediating the pathological loss of synapses in Alzheimer's disease. However, it is not established whether the complement system has a similar role in the diseases Parkinson's disease, Dementia with Lewy bodies, and multiple system atrophy (MSA) that are associated with a-synuclein aggregate pathology.

Methods: To investigate if the complement system has a pathological role in synucleinopathies, we assessed the effect of the complement system on the viability of an a-synuclein expressing cell model and examined direct activation of the complement system by a-synuclein in a plate-based activation assay. Finally, we investigated the levels of the initiator of the classical pathway, C1q, in postmortem brain samples from MSA patients.

Results: We demonstrate that a-synuclein activates the classical complement pathway and mediates complementdependent toxicity in a-synuclein expressing SH-SY5Y cells. The a-synuclein-dependent cellular toxicity was rescued by the complement inhibitors RaCl (inhibiting C5) and Cp20 (inhibiting C3). Furthermore, we observed a trend for higher levels of $\mathrm{Clq}$ in the putamen of MSA subjects than that of controls.

Conclusion: a-Synuclein can activate the classical complement pathway, and the complement system is involved in a-synuclein-dependent cellular cytotoxicity suggesting the system could play a prodegenerative role in synucleinopathies.
\end{abstract}

Keywords: a-Synuclein, Complement system, MSA, Neurodegeneration, SH-SY5Y, RaCl, Cp20

\footnotetext{
* Correspondence: phj@biomed.au.dk

'DANDRITE, The Danish Research Institute of Translational Neuroscience,

Aarhus University, Aarhus C, Denmark

2Department of Biomedicine, Aarhus University, Aarhus C, Denmark

Full list of author information is available at the end of the article
}

(c) The Author(s). 2021 Open Access This article is licensed under a Creative Commons Attribution 4.0 International License, which permits use, sharing, adaptation, distribution and reproduction in any medium or format, as long as you give appropriate credit to the original author(s) and the source, provide a link to the Creative Commons licence, and indicate if changes were made. The images or other third party material in this article are included in the article's Creative Commons licence, unless indicated otherwise in a credit line to the material. If material is not included in the article's Creative Commons licence and your intended use is not permitted by statutory regulation or exceeds the permitted use, you will need to obtain permission directly from the copyright holder. To view a copy of this licence, visit http://creativecommons.org/licenses/by/4.0/ The Creative Commons Public Domain Dedication waiver (http://creativecommons.org/publicdomain/zero/1.0/) applies to the data made available in this article, unless otherwise stated in a credit line to the data. 


\section{Background}

The neuronal protein $\alpha$-synuclein ( $\alpha$-syn) is predominantly located in the pre-synapse, where it is involved in the synaptic vesicle release cycle $[1,2] . \alpha$-Syn is genetically and pathologically associated with a group of neurodegenerative diseases, synucleinopathies, which is dominated by Parkinson's disease (PD), multiple system atrophy (MSA), and dementia with Lewy bodies (DLB) [3, 4]. A common feature for the diseases is the presence of intracellular protein inclusions rich in aggregated $\alpha$-syn [5]. It is believed that aggregated species of $\alpha$-syn facilitate the progressive neuropathology by affecting the functionality of the neuron accumulating the aggregates and transmitting the seeding competent $\alpha$-syn to connected neurons where they in a prion-like manner templated the aggregation of the endogenous $\alpha$-syn of the recipient neurons [6-8]. Besides $\alpha$-syn pathology, neurodegeneration in synucleinopathies is accompanied by extensive neuroinflammation, and several studies have linked both the innate and the adaptive immune systems to PD development $[9,10]$. This is supported by epidemiological findings that anti-inflammatory treatment, e.g., by ibuprofen, reduces the risk of developing PD $[11,12]$, supporting a role for immune and associated signaling systems in synucleinopathies [13].

Traditionally, the immune system has been divided into an adaptive and an innate immune system although it now is evident the immune system is very interactive. Part of the innate immune system is represented by the complement system, which is critical for fast recognition and clearance of pathogens, dying cells, and misfolded proteins [14]. Upon recognition of foreign or altered structures in the body, activation of the complement system initiates a number of anti-microbial defense mechanisms: (1) potent inflammatory mediators are released (such as the fragment C5a), (2) the formation of a membrane attack complex (MAC) leading to the formation of a cytotoxic pore in the target cell membrane, and (3) deposited complement fragments C4b and C3b functioning as molecular tags (opsonins) that can interact with complement receptors on immune cells, thereby facilitating engulfment by phagocytes and activation of B-cells. The launch of the complement system occurs when one or more of three convergent pathways of activation are initiated: the classical, the alternative, or the lectin pathway. The classical pathway is initiated by direct binding of $\mathrm{C} 1$ to a pathogen or through the binding to IgGs covering a pathogen. $\mathrm{C} 1$ is then able to cleave and activate the complement factors $\mathrm{C} 2$ and $\mathrm{C} 4$, which covalently attach to nearby surfaces via exposed reactive thioesters. This leads to the formation of more active enzyme complexes resulting in the effector functions mentioned above. The $\mathrm{C} 1$ complex consists of the recognition molecules $\mathrm{C} 1 \mathrm{q}$ and the two proteases $\mathrm{C} 1 \mathrm{r}$ and $\mathrm{C} 1 \mathrm{~s}$, which are formed by $\mathrm{Ca}^{2+}$-dependent interactions [15].
Although the classic view of the complement system is to be active in blood and other body fluids, it is shown to have functions in the central nervous system (CNS) as well. In the developing brain, complement factor $\mathrm{C} 1 \mathrm{q}$ facilitates the crucial and physiological clearance of cells and the elimination of synapses [16]. This system can later in life be dysfunctionally activated and be involved in the pathological loss of synapses in Alzheimer's disease [17]. Recent animal experiments suggest a similar role in synucleinopathies [18]. Lewy bodies in the substantia nigra are immunohistochemically positive for complement factors C3d and C4d, whereas the levels of distinct complement factor isotypes are decreased in cerebrospinal fluid of PD patients [19, 20]. Similarly, C3 levels are decreased in cerebrospinal fluid of MSA subjects [21]. Complement factor C4 and C5 have been identified as binding partners of oligomeric $\alpha$-syn, and a recent proteome study demonstrated that the complement system is differently expressed in two mouse models of PD [18, 22]. This corroborates a hypothesis where the complement system is involved in $\alpha$-syndependent cell loss in synucleinopathies.

In this study, we demonstrate a direct C1q-dependent activation of the classical complement cascade by $\alpha$-syn that may be responsible for the complement-dependent activity in human plasma that mediates its cytotoxicity toward $\alpha$-syn expressing cells. This association between $\alpha$-syn, a key player in common neurodegenerative diseases, and the innate immune system may form the basis for novel strategies for treating PD and DLB.

\section{Materials and methods}

\section{Serum and recombinant proteins}

All human sera used in this report were drawn from healthy donors (five men (aged 25-60) and three women (aged 28-55)) except for the C1q-depleted serum (Quidel-A509). After clotting of the blood at room temperature, the tubes were centrifuged at $2000 \mathrm{rpm}$ for $10 \mathrm{~min}$ at $4^{\circ} \mathrm{C}$. The serum was isolated and stored at $-80^{\circ} \mathrm{C}$. The storage time varied from months to years. Heat inactivation of complement factors was achieved by incubation of a sample in a $56^{\circ} \mathrm{C}$ water bath for $30 \mathrm{~min}$. Such heat treatment is known to inactivate, e.g., complement factors $\mathrm{C} 2$ and Factor B [23]. We did not observe any significant difference in complement activity between donors, which correlates with published literature, where sex and age were found to have minimal effect on the classical complement pathway [24].

Recombinant human $\alpha$-syn, C-terminally truncated $\alpha$ syn1-95, and $\beta$-synuclein ( $\beta$-syn) were purified from $E$. coli as described in Lindersson et al., which includes a reverse-phase chromatography step that limits lipid contamination [25]. Full-length Tau expressed in E. coli 
were purified as described by Jensen et al. [26]. Sizeexclusion chromatography analysis of $\alpha$-syn was carried out using a Superdex 200 Increase 3.2/300 column (Cytiva-28990946). The size of eluted $\alpha$-syn was estimated using standard protein weight markers (Sigma Aldrich-MWGF1000). Lipopolysaccharide (LPS) was depleted by running the sample through a Detoxi-gel endotoxin removing column (Thermo Fisher-20344). C1q was purified as described in detail by Tenner et al. [27]. In short, C1q was isolated from human serum by binding to BioRex-70 beads followed by elution with a high-salt gradient.

\section{Cell experiments}

SH-SY5Y cell clones with inducible expression of $\beta$ galactosidase $(\beta$-gal) or $\alpha$-syn were a kind gift from Professor Leonidas Stefanis and Associate Professor Kostas Vekrellis, Academy of Athens, Greece. The Tetoff system consists of a Tet-off vector and a pTRE-2 vector encoding $\alpha$-syn or $\beta$-gal [28]. Cells were cultured in RPMI 1640 (Lonza) supplemented with 15\% fetal calf serum (FCS, Biowest-S1810), $50 \mathrm{U} / \mathrm{mL} / 50 \mu \mathrm{g} / \mathrm{mL}$ penicillin/streptomycin, $250 \mu \mathrm{g} / \mathrm{mL}$ G418, and $50 \mu \mathrm{g} / \mathrm{mL}$ Hygromycin $\mathrm{B}$ and maintained at $37^{\circ} \mathrm{C}, 5 \% \mathrm{CO}_{2}$. For experiments, SH-SY5Y cells were seeded in poly-L-lysine (Sigma Aldrich-P4707)-coated 96-well plates and differentiated in media containing 15\% FCS, $20 \mu \mathrm{M}$ alltrans retinoic acid (Molecular Probes/Invitrogen), and 1 $\mu \mathrm{g} / \mathrm{mL}$ doxycycline (Sigma Aldrich-324385). All-trans retinoic acid was included to make the cells non-mitotic. This allows for longer incubation time and development of $\alpha$-syn-aggregated pathology, as demonstrated by Betzer et al. [29]. Two days postseeding, media were replaced with RPMI 1640 containing $20 \mu \mathrm{M}$ all-trans retinoic acid and 15\% normal human serum or heatinactivated human serum. Serum was pooled from at least three donors. In some experiments, $5 \mu \mathrm{M} \mathrm{RaCI}(\mathrm{C} 5$ inhibitor, a kind gift from Matthijs Jore, Oxford University) or $20 \mu \mathrm{M}$ Cp20 (C3 inhibitor, a kind gift from Daniel Ricklin, University of Pennsylvania) was combined with normal human serum media. The simultaneous removal of dox initiated the expression of $\beta$-gal or $\alpha$-syn. On day 12 , viability was determined by an MTT assay (Life Technologies).

\section{Complement activation assay}

Complement activation was measured as $\mathrm{C} 4 \mathrm{~b}$ deposition onto surfaces of microtiter wells using a time-resolved immunofluorometric assay (TRIFMA). 96-well FluoroNunc plates (Thermo Scientific-437958) were coated overnight at $4{ }^{\circ} \mathrm{C}$ with $100 \mu \mathrm{L}, 5 \mu \mathrm{g} / \mathrm{mL}$, recombinant $\alpha$ syn, $\alpha-\operatorname{syn}(1-95), \beta$-syn, Tau, or carbonic anhydrase (Sigma Aldrich-MWGF1000) before being blocked with human serum albumin (HSA, Statens Serum Institute,
Copenhagen, Denmark) at $1 \mathrm{mg} / \mathrm{ml}$ in TBS (10 mM Tris, $145 \mathrm{mM} \mathrm{NaCl}, \mathrm{pH}$ 7.4), for $1 \mathrm{~h}$ at room temperature (RT). Wells to be coated with only HSA were kept empty until this step. Following three times washing in TBS with $0.05 \%$ TWEEN 20, a serial dilution of normal human serum in $4 \mathrm{mM}$ barbital, $145 \mathrm{mM}$ $\mathrm{NaCl}, 3.8 \mathrm{mM} \mathrm{NaN}_{3}$, pH 7.5 supplemented with either 2 $\mathrm{mM} \mathrm{CaCl} 2$ and $1 \mathrm{mM} \mathrm{MgCl}_{2}$ or $10 \mathrm{mM}$ EDTA $\left(\mathrm{Ca}^{2+}\right.$ depleted) was added. The plates were incubated at $37^{\circ} \mathrm{C}$ for $1 \mathrm{~h}$ and subsequently washed three times in $200 \mu \mathrm{L}$ TBS, $0.05 \%$ TWEEN 20, $5 \mathrm{mM} \mathrm{Ca}^{2+}$. Complement activation and thus deposition of complement fragments was assessed by adding $1 \mu \mathrm{g} / \mathrm{mL}$ biotinylated rabbit antibody reacting with an epitope exposed on cleaved forms of C4 (granted by Wolbink and colleagues [30]), at $4^{\circ} \mathrm{C}$ overnight. Following a washing step, the plates were incubated with $0.1 \mu \mathrm{g} / \mathrm{mL}$ Streptavidin-Europium (DELFIA ${ }^{\circ}$ 1244-360) in TBS, 0.05\% TWEEN 20, $25 \mu$ M EDTA for 1 $\mathrm{h}$ at RT. After a three final washes in TBS, 0.05\% TWEEN $20,5 \mathrm{mM} \mathrm{Ca}^{2+}$, the europium in the wells was quantified by time-resolved fluorometry on a Victor ${ }^{\mathrm{mm}} \mathrm{X} 3$ Plate Reader, after addition of an enhancement buffer: $0.57 \%(\mathrm{v} /$ v) acetic acid, $1 \%(\mathrm{w} / \mathrm{v})$ PEG 6000, 0.1\% (v/v) Triton X$100,15 \mu \mathrm{M} \beta$-napthoyltrifluoroacetone, $50 \mu \mathrm{M}$ tri-noctylphosphine oxide, $\mathrm{pH} 3.2$.

\section{Human brain samples and western blotting}

Human brain samples were obtained from Sydney Brain Bank and NSW Tissue Resource Centre. Controls were free of neuropathology, while MSA donors were diagnosed clinically and pathologically in accordance with international diagnostic criteria [31]. Brain tissue from the putamen or visual cortex was collected from frozen brain slices using a 3-mm stainless steel biopsy needle. Clinical information (i.e., age, gender, postmortem interval (PMI), disease duration) is summarized in Table 1.

Table 1 Demographic information on MSA and control cases

\begin{tabular}{rllll}
\hline Brain ID & Age & Gender & PMI (hours) & Disease duration (years) \\
\hline MSA & & & & \\
MSA1 & 61 & Male & 21 & 4 \\
MSA2 & 82 & Male & 8 & 7 \\
MSA3 & 74 & Male & 16 & 10 \\
MSA4 & 67 & Male & 11 & 8 \\
Mean & $71 \pm 7.8$ & & $14 \pm 4.9$ & $7.3 \pm 2.2$ \\
Control & & & & \\
Con1 & 69 & Male & 13.5 & N/A \\
Con2 & 85 & Male & 9 & N/A \\
Con3 & 65 & Male & 14.5 & N/A \\
Con4 & 88 & Male & 9 & N/A \\
Mean & $76.8 \pm 9.9$ & & $11.5 \pm 2.5$ &
\end{tabular}

$P M I$ postmortem interval. There was no statistically significant difference in age and PMI between MSA and controls. Statistical test: Student's $t$-test 
For more details on the brain samples, we refer to Don et al. [32]. Tissue was dounce homogenized in ice-cold $250 \mathrm{mM}$ sucrose, $10 \mathrm{mM}$ HEPES, $1 \mathrm{mM}$ EDTA, $\mathrm{pH} 7.4$ containing protease inhibitors $(1 \mu \mathrm{g} / \mathrm{mL}$ pepstatin-A, $1 \mathrm{mM}$ benzamidine, $1 \mu \mathrm{g} / \mathrm{mL}$ leupeptin, $1 \mu \mathrm{g} / \mathrm{mL}$ aprotinin; Roche Applied Science). Homogenates were centrifuged $800 \mathrm{~g}$, at $4^{\circ} \mathrm{C}$ for $10 \mathrm{~min}$ and the supernatant was collected as the soluble fraction of the brain extracts. Protein, $40 \mu \mathrm{g}$, from the soluble fraction was run on SDS-page ( $8 \%$ acrylamide) and transferred to nitrocellulose membranes. Following overnight blocking with PBS containing 5\% non-fat dry milk for $2 \mathrm{~h}$ at $4^{\circ} \mathrm{C}$, the membranes were incubated with primary antibodies (rabbit anti-C1q, DAKO A136, 1/1000 dilution or mouse anti- $\beta$-actin, Abcam ab6276, 1/10,000 dilution) in PBS containing 5\% non-fat dry milk overnight at $4^{\circ} \mathrm{C}$. Next, membranes were washed three times in PBS containing $0.1 \%$ Tween 20 before being subjected to secondary antibody conjugated to horseradish peroxidase (anti-rabbit, Dako P0448 or anti-mouse, Bio-Rad 170-6516, 1/2000 dilution) in PBS containing 5\% non-fat dry milk for $2 \mathrm{~h}$. Bands were visualized using enhanced chemiluminescence (ECL, GE Healthcare, Buckinghamshire, UK) and Xray films. Densitometric quantification was performed using ImageJ.

\section{Statistics}

Initially, a Shapiro-Wilk test was used to determine if data fitted a normal distribution. When comparing two groups, a ratio paired Student's $t$-test was used to test the null hypothesis. For multiple comparisons, one-way ANOVA followed by Tukey's multiple comparison test was conducted. $P$-values $<0.05$ were considered statistically significant. All statistical analyses were performed using GraphPad Prism 8.4.1.

\section{Results}

Alpha-synuclein activates the classical complement cascade The complement system has been implicated in the neurodegeneration associated with $\mathrm{AD}$. We hypothesized that it also contributes to the neurodegeneration in the synucleinopathies; PD, DLB, and MSA that are characterized by $\alpha$-syn aggregate associated neurodegeneration and neuroinflammation. To test the hypothesis, we cultivated human SH-SY5Y cells under non-mitotic conditions and induced expression of $\alpha$-syn by removal of doxycycline to induce $\alpha$-syndependent cell stress [29]. Heat inactivation of serum is used as a routine method to inactivate the complement system in cell culture supplement. Culturing SH-SY5Y cells expressing $\alpha$-syn for 10 days in the presence of not heat-inactivated human serum resulted in a $15 \%$ reduction in viability compared to SH-SY5Y cells expressing $\beta$-gal as a negative control protein (Fig. 1A). In contrast, no $\alpha$-syn-dependent reduction in viability was observed when the cells were cultured in the presence of human serum where the complement system had been inactivated by heat treatment. To corroborate a role for complementdependent components in $\alpha$-syn-induced cytotoxicity, we tested the effect of two specific inhibitors of complement components: $\mathrm{RaCI}$ for complement component C5 [33] and CP20 for complement component C3 [34]. Addition of either inhibitor to the culture medium containing non-heat-inactivated serum completely rescued the $\alpha$-syn-dependent cell loss without exerting toxicity on the $\beta$-gal expressing cells (Fig. 1B). This demonstrates that cellular $\alpha$-syn stress triggers a complement-dependent cytotoxic pathway that contributes to the demise of the cells.

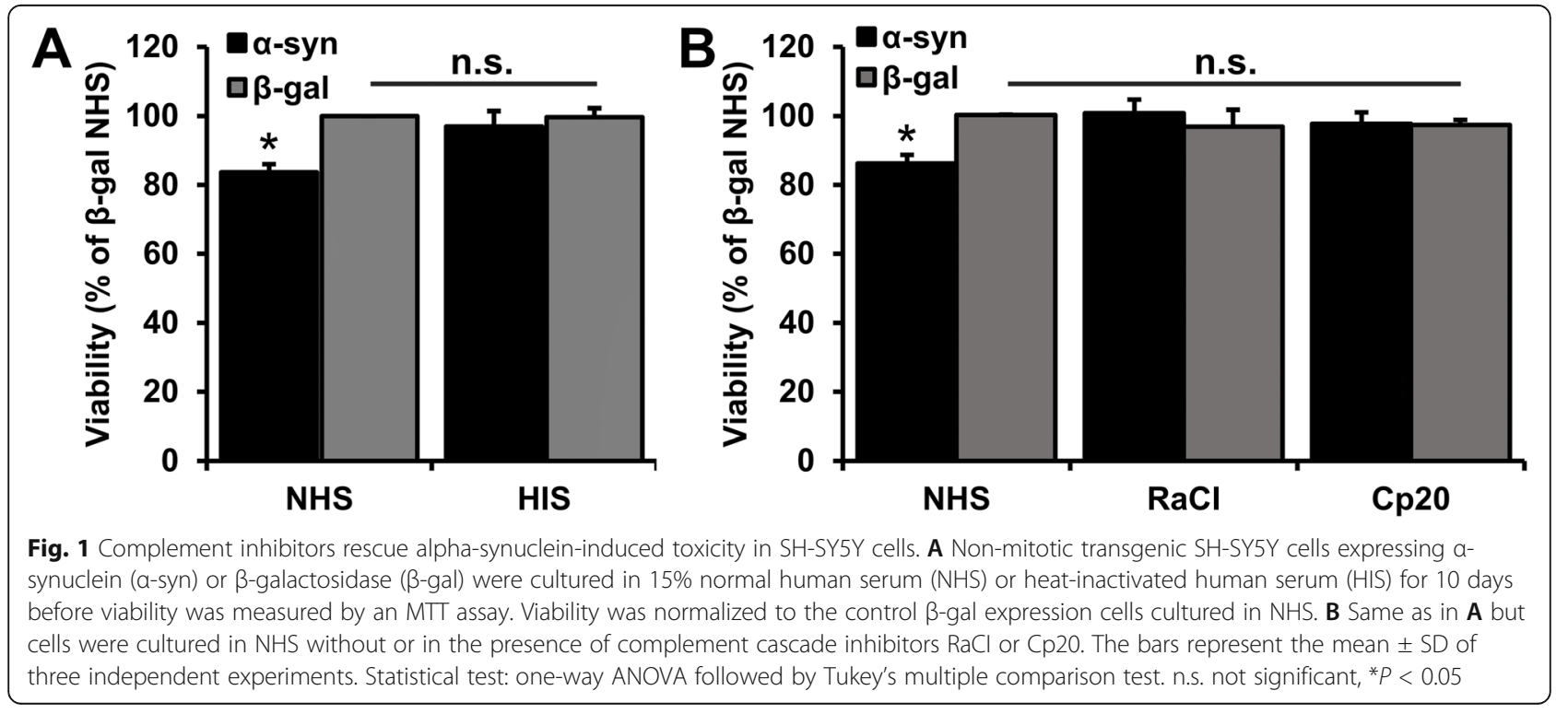


To investigate if $\alpha$-syn directly can activate the complement system, we used a plate-based immunoassay to investigate if immobilized $\alpha$-syn can stimulate the complement-dependent deposition of complement factor C4b on the surface of $\alpha$-syn-coated microtiter plates. Size-exclusion chromatography analysis showed the purified $\alpha$-syn used for coating was almost exclusively monomeric (>98\%) (Fig. 2A). $\alpha$-Syn stimulates the deposition of $\mathrm{C} 4 \mathrm{~b}$ when co-incubated with non-heatinactivated human serum. The activation of complement in serum is calcium dependent, and the deposition of $\mathrm{C} 4$ fragments was abolished in $\mathrm{Ca}^{2+}$-free buffer (Fig. 2B). The $\alpha$-syn used for the experiment is expressed in $E$. coli, so contaminating lipopolysaccharide (LPS) could in principle be responsible for the activation, although this is primarily known for the $\mathrm{C} 3 \mathrm{~b}$ depositing alternative pathway. However, treatment of the $\alpha$-syn with an LPS removal kit had no effect on the complement activation (Fig. 2C). Carbonic anhydrase and Alzheimer's diseaseassociated Tau did not facilitate C4b deposition (Fig. 2D). This emphasizes the specificity of $\alpha$-syn in activating the complement system. Interestingly, $\beta$-synuclein ( $\beta$-syn) were equally capable of activating the complement system (Fig. 2E). The C-terminal part of $\alpha$-syn is important in mediating the $\mathrm{C} 4 \mathrm{~b}$ deposition, as the activation was greatly reduced when coating with a C-terminally truncated $\alpha-\operatorname{syn}(1-95)$ (Fig. 2E). To investigate if $\alpha$-syndependent deposition of $\mathrm{C} 4$ fragments was mediated by the classical pathway, we tested the effect of immunedepleting $\mathrm{C} 1 \mathrm{q}$, the first initial component of the classical complement pathway from the activation assay. We found $\mathrm{C} 1 \mathrm{q}$ was essential for activation by $\alpha$-syn, as no deposition of $\mathrm{C} 4 \mathrm{~b}$ was present when using C1qdepleted human sera (Fig. 2F). This deposition could be partially recovered by adding physiological levels of $\mathrm{C} 1 \mathrm{q}$ to the serum. Together, our data demonstrate that $\alpha$-syn can activate the classical complement pathway by acting on early steps in the cascade.

\section{C1q levels in multiple system atrophy patients}

MSA is a rare, aggressive neurodegenerative disease that is characterized by the development of $\alpha$-syn aggregate containing inclusions in oligodendrocytes, neurodegeneration, and a strong neuroinflammation. To assess if activation of the classical complement pathway could be involved in MSA pathogenesis, we evaluated the levels of $\mathrm{Clq}$ in the soluble fraction of postmortem tissue extracts from four MSA patients, versus four age-matched healthy controls by western blotting (Fig. 3). We assessed putamen, a brain area typically affected by $\alpha$ syn aggregates and neurodegeneration in MSA, and the visual cortex, which is generally unaffected. The band visualized on the immunoblot in Fig. 3 represents the Achain of complement factor C1q. The analysis showed a trend toward higher levels of $\mathrm{Clq}$ in the putamen of individuals with MSA, where three MSA patients exhibited high $\mathrm{C} 1 \mathrm{q}$ levels compared to neurological healthy individuals, but it did not reach statistical significance $(P=0.15)$. The $\mathrm{Clq}$ levels in the visual cortex were similar for MSA and control samples $(P=0.68)$.

In summary, we have shown that $\alpha$-syn directly activates the classical complement pathway and in cells confers a complement-dependent component to the molecular $\alpha$-syn cytotoxicity. Moreover, in MSA patients, $\mathrm{C} 1 \mathrm{q}$ levels tended to be increased in the putamen that is affected by this disease.

\section{Discussion}

The complement system is a critical component in the development and homeostasis of neuronal networks in the CNS $[16,35]$ where $\mathrm{C} 1$ and $\mathrm{C} 3$ may serve as eat-me signals for microglia-dependent nibbling of synapses [35-37]. It may also play a detrimental role in diseased states as the $\beta$-amyloid mediated loss of synapses in an Alzheimer's disease mouse model was dependent on complement activation [17], and increased complement activation has been demonstrated in the substantia nigra of PD patients [38]. Our data support a hypothesis whereby $\alpha$-syn-dependent complement activation in neurons can contribute to the microglia activation due to increased C3b deposition.

We report as a novel finding that immobilized $\alpha$-syn directly can activate the classical complement pathway in vitro and demonstrate that cellular expression of $\alpha$ syn contributes to complement-dependent cytotoxicity in a neuronal cell line. The activation relied on cellular $\alpha$-syn expression and may depend on its binding to the cell surfaces that hold receptors for the $\alpha$-syn [39-42].

We found that immobilized $\alpha$-syn was able to activate the classical pathway, which resulted in the deposition of C4b. In a similar manner, $\alpha$-syn can be presented on the cell surface by binding of secreted $\alpha$-syn to cell surface receptors, by the formation of membrane spanning pores, or by its presentation on extracellular vesicles released from cells [43-45]. Here, it can potentially be recognized by $\mathrm{C} 1 \mathrm{q}$, and thereby initiate the classical complement pathway. If not adequately controlled, the complement system can induce cell death by the formation of the membrane attack complex [46] (Fig. 4), a mechanism we find most likely to be active in our cell model that is devoid of immune cells. Such a role is corroborated by the recent demonstration of complement system components to be differently expressed in two different mouse models of PD [18]. Complement activation does not seem to be dependent on the pathological aggregation of $\alpha$-syn, as the a-syn preparation consisted mostly of monomeric $\alpha$-syn (Fig. 2A). Moreover, the homologue $\beta$-syn, which lacks the NAC region essential 


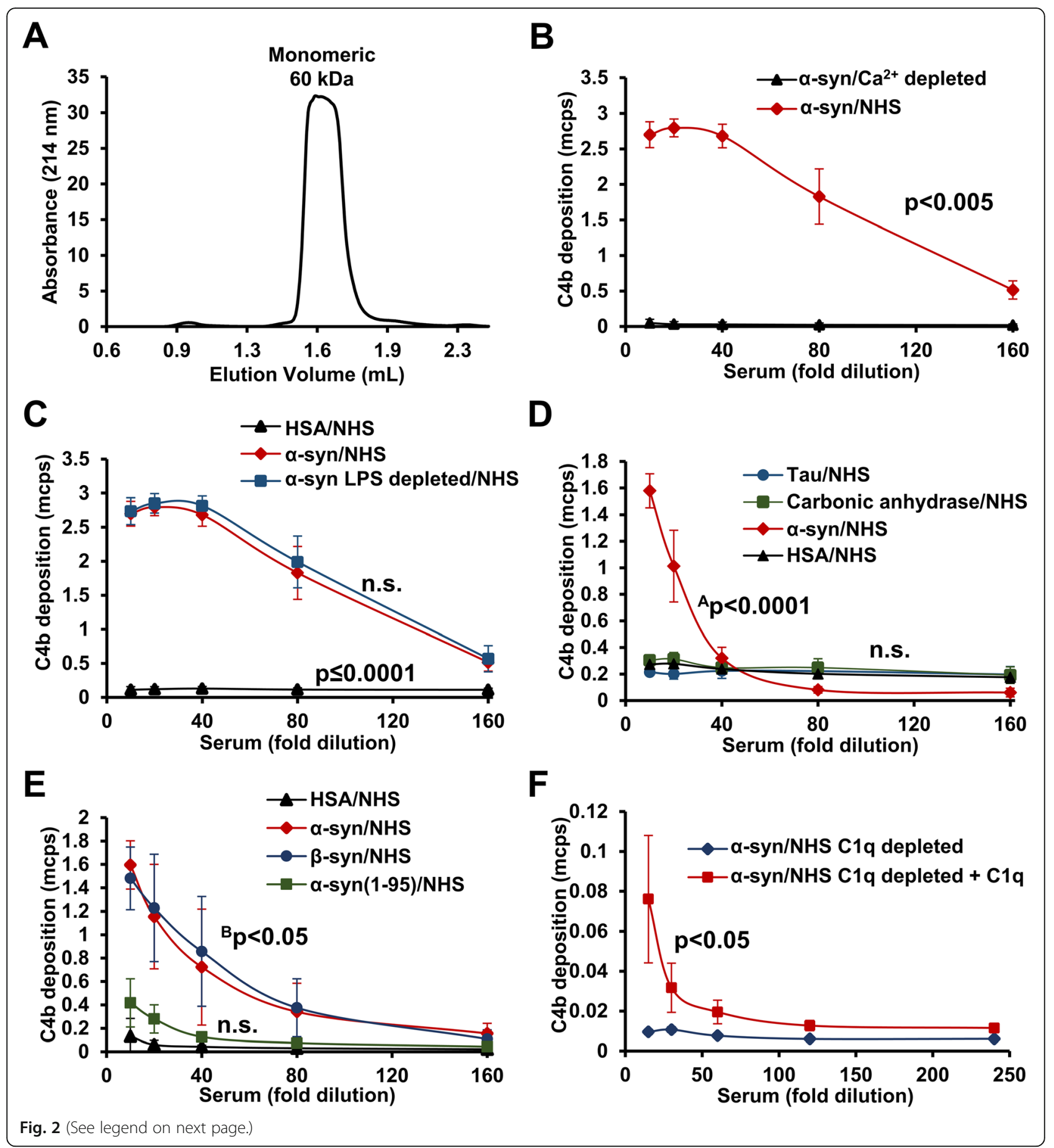


(See figure on previous page.)

Fig. 2 Alpha-synuclein activates the classical complement cascade. A Absorbance profile at $214 \mathrm{~nm}$ of purified a-synuclein (a-syn) subjected to sizeexclusion chromatography analysis. Monomeric $a-s y n$ elutes as a 60-kDa protein due to its natively unfolded state. B Wells coated with a-syn were incubated with normal human serum (NHS) or NHS in the presence of EDTA ( $\mathrm{Ca}^{2+}$ depleted). The deposition of complement was measured using a biotinylated C4b-fragment-specific antibody followed by incubation with streptavidin-europium. Time-resolved fluorescence from the europium is given as million counts per second (mcps). Statistical test: area under the curve (AUC) was compared by a ratio paired t-test. C Same procedure as B except wells were coated with either human serum albumin (HSA), a-syn, or a-syn depleted for lipopolysaccharide (LPS depleted) followed by incubation with NHS. Statistical test: AUC was compared by a one-way ANOVA for repeated measures followed by Tukey's multiple comparison. D Same as B, except wells were coated with HSA, a-syn, Tau, or carbonic anhydrase followed by incubation with NHS. Statistical test: AUC was compared by a one-way ANOVA for repeated measures followed by Tukey's multiple comparison. ${ }^{A} a-S y n$ compared to Tau, carbonic anhydrase, and HSA. E Same as B, except wells were coated with HSA, $a$-syn, $\beta$-synuclein ( $\beta$-syn), or C-terminal truncated $\alpha$-syn ( $\alpha$-syn(1-95)) followed by incubation with NHS. Statistical test: AUC was compared by a one-way ANOVA for repeated measures followed by Tukey's multiple comparison. ${ }^{B}$ a-Syn and $\beta$-syn compared to HSA. F Same as B, except a-syn-coated wells were incubated with C1q-depleted NHS (C1q depleted) without or with added C1q. Statistical test: AUC was compared by a ratio paired $t$-test. All data points are presented as mean \pm SD. B, C, E, F $n=3 ; \mathbf{D} n=5$

for fibrilization, also initiated the complement cascade (Fig. 2E).

In this study, we used human serum as the source for complement factors because it contains all humoral components. The concentrations of the complement factors are higher than in CSF because of the integrity of the blood-brain barrier [47]; however, functional complement factors are produced locally in the brain tissue $[16,48-50]$ where their concentration and activation likely are regulated by the local microenvironment. Utilizing a plate-based immunoassay to quantify the $\mathrm{C} 4 \mathrm{~b}$ deposition, we showed that $\alpha$-syn coated in the microtiter wells activated the complement system in vitro. This is in contrast to a previous study that found the $\alpha$-syn- 112 splice variant but not full-length $\alpha$-syn activated the complement system [51]. The conflicting results could be due to their quantification of the further downstream C5b-9 as opposed to C4b in the present report. Furthermore, we assured our observation was not caused by contaminating LPS in the recombinant $\alpha$-syn preparation, but such assessment was not reported in the previous study. C1q depletion of NHS completely abolished $\alpha$-syn complement deposition while the addition of $\mathrm{C} 1 \mathrm{q}$ partly restored the signal (Fig. 2C). We assume that the absence of complete recovery of the complement activation was due to a possible difference in concentrations of, e.g., C1, C1s, or C4. Nevertheless, taken together, this data strongly suggest the classical pathway is activated by $\alpha$-syn.

To support a role for complement activation in synucleinopathies, we compared C1q levels in tissue from the putamen and visual cortex from MSA patients and
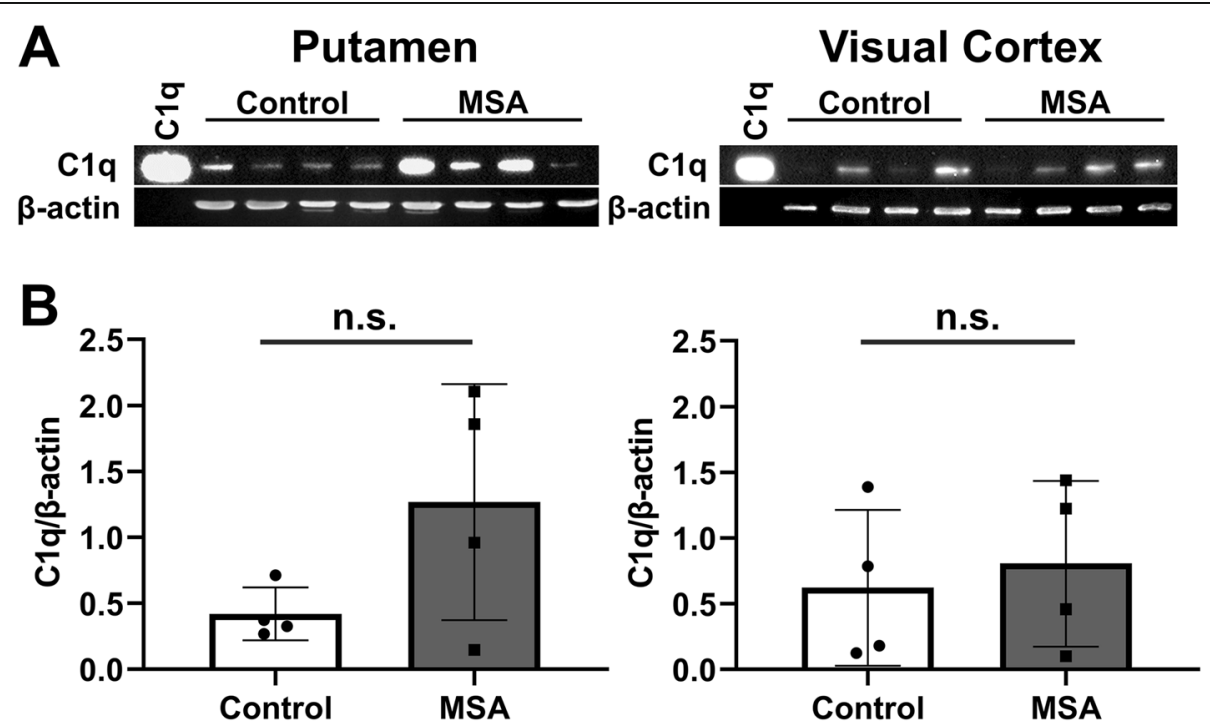

Fig. 3 Comparison of complement factor C1q levels in the putamen and visual cortex in healthy controls and multiple system atrophy patients. A Tissue from the putamen and visual cortex from 4 patient brains affected by multiple system atrophy (MSA) patients and 4 brains of healthy age-matched controls were extracted, resolved by SDS-page, and analyzed by immunoblotting for the presence of C1q and $\beta$-actin. Purified C1q was included as a positive control. B C1q and $\beta$-actin bands were quantified by densitometry using ImageJ and displayed as the ratio between the two. Points refer to the individual samples, while the column displays mean \pm SD. Statistical test: mean compared by Welch's $t$ test. n.s. not significant. Full blots can be found in the supplementary material 


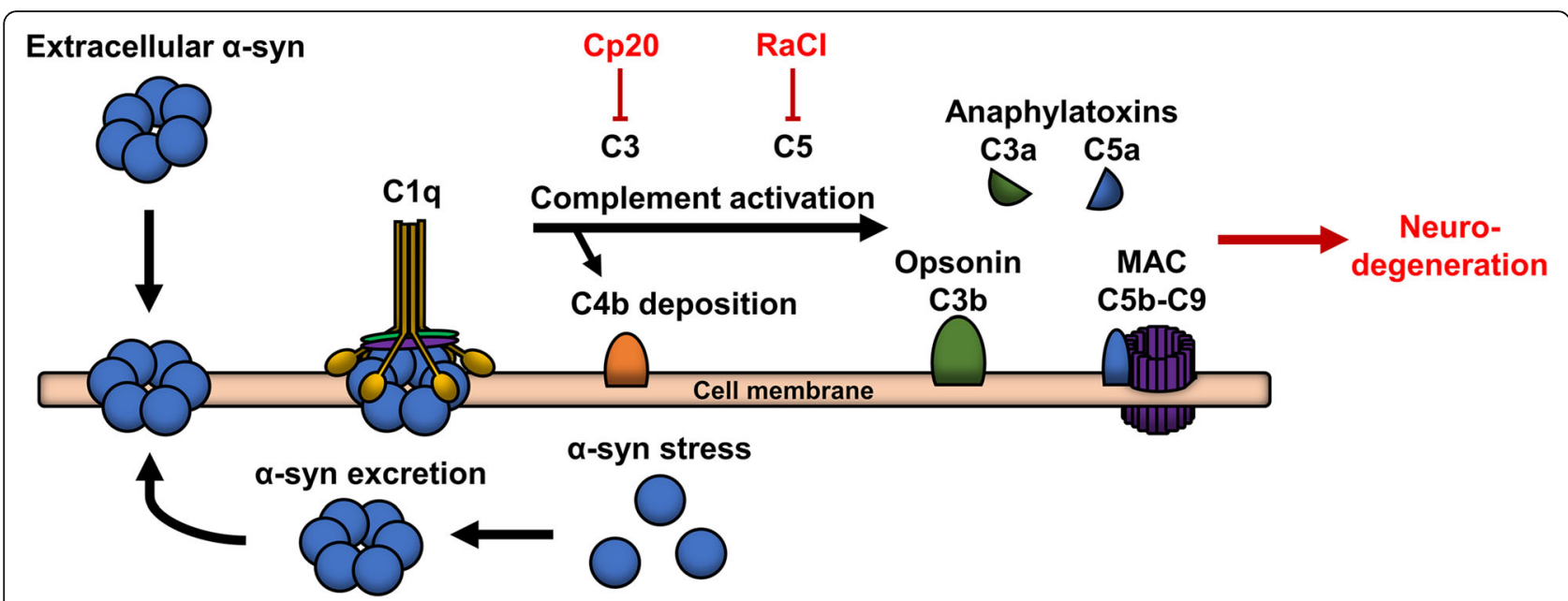

Fig. 4 Hypothetical mechanism for a-synuclein mediated complement-dependent cytotoxicity. Intracellular a-synuclein (a-syn) stress, excretion of a-syn-covered extracellular vesicles, or binding of extracellular a-syn to the cell surface leads to the presentation of a-syn at the plasma membrane. Here, a-syn could potentially activate the classical complement cascade by direct binding of C1 leading to deposition of C4b, production of anaphylatoxins, C3a opsonization, and the formation of the membrane attack complex (MAC). Complement inhibitors, exemplified by Cp20 and RACl, holds neuroprotective potential by making the cell inert to the binding of C1q to membrane-associated a-syn

controls. MSA is characterized by a strong accumulation of $\alpha$-syn pathology in the putamen but not the visual cortex. We observed increased putaminal C1q levels in three of the four MSA cases. Statistical significance was not achieved due to one case being very low. However, the observation justifies larger comparative studies of complement levels not only in brain tissue affected by MSA but also in other synucleinopathies like PD and DLB.

The realization that the complement system is involved in numerous disease states has led to therapeutic strategies that modulate specific complement components [52]. Our demonstration of targeting C3 and C5 with $\mathrm{CP} 20$ and $\mathrm{RaCl}$ is protective in our cell model against $\alpha$-syn-dependent complement-mediated cytotoxicity supports complement targeting disease-modifying strategies also may hold potential in PD and other synucleinopathies.

\section{Conclusion}

In conclusion, our results demonstrate that $\alpha$-syn can activate the classical pathway of the complement system and this system contributes to $\alpha$-syn-dependent cytotoxicity. This suggests the complement system contributes to the neurodegeneration of MSA and related synucleinopathies.

\section{Abbreviations}

a-syn: a-Synuclein; $\beta$-gal: $\beta$-Galactosidase; $\beta$-syn: $\beta$-Synuclein; CNS: Central nervous system; DLB: Dementia with Lewy bodies; FCS: Fetal calf serum; HIS: Heat-inactivated serum; HSA: Human serum albumin;

LPS: Lipopolysaccharide; MAC: Membrane attack complex; MSA: Multiple system atrophy; NHS: Normal human serum; PD: Parkinson's disease;

RT: Room temperature; TRIFMA: Time-resolved immunofluorometric assay

\section{Supplementary Information}

The online version contains supplementary material available at https://doi. org/10.1186/s12974-021-02225-9.

Additional file 1. Full western blot from Figure 3 with protein ladder.

\section{Acknowledgements}

Not applicable

\section{Authors' contributions}

EG: project design, analysis and interpretation of plate-based immuno-assays, data curation, and manuscript drafting. CB: performed cell experiments and project design. WSK: brain tissue processing and western blot. GK and LR: experiment design and manuscript revision. GMH, ST, and PHJ: project supervision, manuscript review, and editing. The authors read and approved the final manuscript.

\section{Funding}

The study was supported by LundbeckFoundation grants R223-2015-4222 for PHJ, R248-2016-2518 for Danish Research Institute of Translational

Neuroscience-DANDRITE, Nordic-EMBL Partnership for Molecular Medicine, Aarhus University, Denmark. EG was generously supported for his PhD study by Lundbeck A/S. GK was supported by the Novo Nordisk Foundation Distinguished Innovator 1-2020 grant. LR was supported by EU Multinational research projects on Personalised Medicine for Neurodegenerative Diseases (JPND2019) to project OligoFIT. Control and MSA brain tissue were received from the Sydney Brain Bank which is supported by Neuroscience Research Australia and the University of New South Wales. The longitudinal collection of the cohort was supported by National Health and Medical Research Council (NHMRC) funding to ForeFront, a collaborative research group at the Brain and Mind Centre University of Sydney. GMH is an NHMRC Leadership Fellow (\#1176607).

Availability of data and materials

All relevant data are available upon request directed to the corresponding author.

\section{Declarations}

Ethics approval and consent to participate Ethics approval (HC16568) was from the University of New South Wales Human Research Ethics Committee. 


\section{Consent for publication}

Not applicable

\section{Competing interests}

The authors declare that they have no competing interests.

\section{Author details}

'DANDRITE, The Danish Research Institute of Translational Neuroscience, Aarhus University, Aarhus C, Denmark. ${ }^{2}$ Department of Biomedicine, Aarhus University, Aarhus C, Denmark. ${ }^{3}$ Brain and Mind Centre \& Faculty of Medicine and Health, School of Medical Sciences, The University of Sydney, Camperdown, New South Wales, Australia.

\section{Received: 12 January 2021 Accepted: 21 July 2021}

\section{Published online: 16 August 2021}

\section{References}

1. Cabin DE, Shimazu K, Murphy D, Cole NB, Gottschalk W, Mcllwain KL, et al. Synaptic vesicle depletion correlates with attenuated synaptic responses to prolonged repetitive stimulation in mice lacking a-synuclein. J Neurosci. 2002;22(20):8797-807. https://doi.org/10.1523/jneurosci.22-20-08797.2002.

2. Logan T, Bendor J, Toupin C, Thorn K, Edwards RH. a-Synuclein promotes dilation of the exocytotic fusion pore. Nat Neurosci. 2017;20(5):681-9. https://doi.org/10.1038/nn.4529.

3. Spillantini MG. Parkinson's disease, dementia with Lewy bodies and multiple system atrophy are a-synucleinopathies. Parkinsonism Relat Disord. 1999: 5(4):157-62. https://doi.org/10.1016/S1353-8020(99)00031-0.

4. Goedert M, Spillantini MG. Lewy body diseases and multiple system atrophy as a-synucleinopathies. Mol Psychiatry. 1998;3(6):462-5. https://doi.org/10.1 038/s.mp. 4000458 .

5. Stefanis L. a-Synuclein in Parkinson's disease. Cold Spring Harb Perspect Med. 2012;2(2):a009399. https://doi.org/10.1101/cshperspect.a009399.

6. Braak H, Del Tredici K, Rüb U, de Vos RA, Jansen Steur EN, Braak E. Staging of brain pathology related to sporadic Parkinson's disease. Neurobiol Aging. 2003:24(2):197-211. https://doi.org/10.1016/50197-4580(02)00065-9.

7. Li J-Y, Englund E, Holton JL, Soulet D, Hagell P, Lees AJ, et al. Lewy bodies in grafted neurons in subjects with Parkinson's disease suggest host-to-graft disease propagation. Nat Med. 2008;14(5):501-3. https://doi.org/10.1038/ nm1746.

8. Kordower JH, Chu Y, Hauser RA, Olanow CW, Freeman TB. Transplanted dopaminergic neurons develop PD pathologic changes: a second case report. Mov Disord. 2008:23(16):2303-6. https://doi.org/10.1002/mds.22369.

9. McGeer PL, Itagaki S, Boyes BE, McGeer EG. Reactive microglia are positive for HLA-DR in the substantia nigra of Parkinson's and Alzheimer's disease brains. Neurology. 1988;38(8):1285-91. https://doi.org/10.1212/wnl.38.8.1285.

10. Brochard V, Combadière B, Prigent A, Laouar Y, Perrin A, Beray-Berthat V, et al. Infiltration of $C D 4+$ lymphocytes into the brain contributes to neurodegeneration in a mouse model of Parkinson disease. J Clin Invest. 2009;119(1):182-92. https://doi.org/10.1172/JC136470.

11. Chen H, Jacobs E, Schwarzschild MA, McCullough ML, Calle EE, Thun MJ et al. Nonsteroidal antiinflammatory drug use and the risk for Parkinson's disease. Ann Neurol. 2005:58(6):963-7. https://doi.org/10.1002/ana.20682.

12. Gagne JJ, Power MC. Anti-inflammatory drugs and risk of Parkinson disease: a meta-analysis. Neurology. 2010;74(12):995-1002. https://doi.org/10.1212/ WNL.0b013e3181d5a4a3.

13. Sabatino JJ, Pröbstel AK, Zamvil SS. B cells in autoimmune and neurodegenerative central nervous system diseases. Nat Rev Neurosci. 2019; 20(12):728-45. https://doi.org/10.1038/s41583-019-0233-2.

14. Bajic G, Degn SE, Thiel S, Andersen GR. Complement activation, regulation and molecular basis for complement-related diseases. EMBO J. 2015;34(22): 2735-57. https://doi.org/10.15252/embj.201591881.

15. Thielens NM, Aude CA, Lacroix MB, Gagnon J, Arlaud GJ. Ca2+ binding properties and $\mathrm{Ca} 2+$-dependent interactions of the isolated $\mathrm{NH2}$-terminal a fragments of human complement proteases Cìr and Cìs. J Biol Chem. 1990;265(24):14469-75. https://doi.org/10.1016/S0021-9258(18)77326-2.

16. Stevens B, Allen NJ, Vazquez LE, Howell GR, Christopherson KS, Nouri N, et al. The classical complement cascade mediates CNS synapse elimination. Cell. 2007:131(6):1164-78. https://doi.org/10.1016/i.cell.2007.10.036

17. Hong S, Beja-glasser VF, Nfonoyim BM, et al. Complement and microglia mediate early synapse loss in Alzheimer mouse models. Science. 2016;8373: 1-9. https://doi.org/10.1126/science.aad8373.
18. Ma SX, Kim D, Xiong Y, et al. Complement and coagulation cascades are potentially involved in dopaminergic neurodegeneration in a-synucleinbased mouse models of Parkinson's disease. bioRxiv. 2020;2020(1):11.900886 https://doi.org/10.1101/2020.01.11.900886.

19. Yamada T, McGeer PL, McGeer EG. Lewy bodies in Parkinson's disease are recognized by antibodies to complement proteins. Acta Neuropathol. 1992; 84(1):100-4. https://doi.org/10.1007/BF00427222.

20. Finehout EJ, Franck Z, Lee KH. Complement protein isoforms in CSF as possible biomarkers for neurodegenerative disease. Dis Markers. 2005;21(2): 93-101. http://www.pubmedcentral.nih.gov/articlerender.fcgi?artid=3851 089\&tool=pmcentrez\&rendertype=abstract. https://doi.org/10.1155/2005/ 806573.

21. Wang Y, Hancock AM, Bradner J, Chung KA, Quinn JF, Peskind ER, et al. Complement 3 and factor $\mathrm{H}$ in human cerebrospinal fluid in Parkinson's disease, Alzheimer's disease, and multiple-system atrophy. Am J Pathol. 2011;178(4):1509-16. https://doi.org/10.1016/j.ajpath.2011.01.006.

22. Betzer C, Movius AJ, Shi M, Gai WP, Zhang J, Jensen PH. Identification of synaptosomal proteins binding to monomeric and oligomeric a-synuclein. PLoS One. 2015;10(2):1-24. https://doi.org/10.1371/journal.pone.0116473.

23. Joisel F, Leroux-Nicollet I, Lebreton JP, Fontaine M. A hemolytic assay for clinical investigation of human C2. J Immunol Methods. 1983;59(2):229-35. https://doi.org/10.1016/0022-1759(83)90035-2.

24. Da Costa MG, Poppelaars F, Van Kooten C, et al. Age and sex-associated changes of complement activity and complement levels in a healthy Caucasian population. Front Immunol. 2018;9(NOV):2664. https://doi.org/1 0.3389/fimmu.2018.02664.

25. Lindersson E, Lundvig D, Petersen C, Madsen P, Nyengaard JR, Højrup P, et al. p25a stimulates a-synuclein aggregation and is co-localized with aggregated a-synuclein in a-synucleinopathies. J Biol Chem. 2005;280(7): 5703-15. https://doi.org/10.1074/jbc.M410409200.

26. Jensen PH, Hager H, Nielsen MS, Højrup P, Gliemann J, Jakes R. a-synuclein binds to tau and stimulates the protein kinase A-catalyzed tau phosphorylation of serine residues 262 and 356. J Biol Chem. 1999;274(36): 25481-9. https://doi.org/10.1074/jbc.274.36.25481.

27. Tenner A, Lesavre $\mathrm{P}$, Cooper N. Purification and radiolabeling of human C1q J Immunol. 1981;127(2):648-53 http://www.jimmunol.org/content/127/2/64 8.short. Accessed June 16, 2014.

28. Vekrellis $K$, Xilouri $M, E m m a n o u i l i d o u ~ E$, Stefanis L. Inducible over-expression of wild type a-synuclein in human neuronal cells leads to caspasedependent non-apoptotic death. J Neurochem. 2009;109(5):1348-62. https://doi.org/10.1111/j.1471-4159.2009.06054.x.

29. Betzer $C$, Lassen LB, Olsen $A$, et al. Alpha-synuclein aggregates activate calcium pump SERCA leading to calcium dysregulation. EMBO Rep. 2018; e44617. https://doi.org/10.15252/embr.201744617.

30. Wolbink GJ, Bollen J, Baars JW, ten Berge RJM, Swaak AJG, Paardekooper J, et al. Application of a monoclonal antibody against a neoepitope on activated C4 in an ELISA for the quantification of complement activation via the classical pathway. J Immunol Methods. 1993;163(1):67-76. http://www.ncbi.nlm.nih gov/pubmed/7687639. https://doi.org/10.1016/0022-1759(93)90240-8.

31. Wenning GK, Tison F, Seppi K, et al. Development and validation of the Unified Multiple System Atrophy Rating Scale (UMSARS). Mov Disord. 2004; 19(12). https://doi.org/10.1002/mds.20255.

32. Don AS, Hsiao JHT, Bleasel JM, Couttas TA, Halliday GM, Kim WS. Altered lipid levels provide evidence for myelin dysfunction in multiple system atrophy. Acta Neuropathol Commun. 2014;2(1):1-14. https://doi.org/10.11 86/s40478-014-0150-6.

33. Jore MM, Johnson S, Sheppard D, Barber NM, Li YI, Nunn MA, et al. Structural basis for therapeutic inhibition of complement C5. Nat Struct Mol Biol. 2016;23(5):378-86. https://doi.org/10.1038/nsmb.3196.

34. Mastellos DC, Yancopoulou D, Kokkinos P, Huber-Lang M, Hajishengallis G, Biglarnia AR, et al. Compstatin: a C3-targeted complement inhibitor reaching its prime for bedside intervention. Eur J Clin Investig. 2015;45(4): 423-40. https://doi.org/10.1111/eci.12419.

35. Schafer DP, Lehrman EK, Kautzman AG, Koyama R, Mardinly AR, Yamasaki R, et al. Microglia sculpt postnatal neural circuits in an activity and complement-dependent manner. Neuron. 2012;74(4):691-705. https://doi. org/10.1016/j.neuron.2012.03.026

36. Hou L, Bao X, Zang C, Yang H, Sun F, Che Y, et al. Integrin CD11b mediates a-synuclein-induced activation of NADPH oxidase through a Rhodependent pathway. Redox Biol. 2018;14:600-8. https://doi.org/10.1016/j. redox.2017.11.010 
37. Stephan A. The complement system: an unexpected role in synaptic pruning during development and disease. Annu Rev. 2012. https://doi.org/1 0.1146/annurev-neuro-061010.

38. Loeffler DA, Camp DM, Conant SB. Complement activation in the Parkinson's disease substantia nigra: an immunocytochemical study. J Neuroinflammation. 2006;3(1):29. https://doi.org/10.1186/1742-2094-3-29.

39. Mao X, Ou MT, Karuppagounder SS, et al. Pathological alpha-synuclein transmission initiated by binding lymphocyte-activation gene 3. Science. 2016;353(6307):aah3374. https://doi.org/10.1126/science.aah3374.

40. Kim C, Ho DH, Suk JE, You S, Michael S, Kang J, et al. Neuron-released oligomeric a-synuclein is an endogenous agonist of TLR2 for paracrine activation of microglia. Nat Commun. 2013;4(1):1562. https://doi.org/10.103 8/ncomms2534.

41. Stefanova N, Fellner L, Reindl M, Masliah E, Poewe W, Wenning GK. Toll-like receptor 4 promotes a-synuclein clearance and survival of nigral. dopaminergic neurons. Am J Pathol. 2011;179(2):954-63. https://doi.org/10.1 016/j.ajpath.2011.04.013.

42. Surguchev AA, Emamzadeh FN, Surguchov A. Cell responses to extracellular asynuclein. Molecules. 2019;24(2). https:/doi.org/10.3390/molecules24020305.

43. Ferreira DG, Temido-Ferreira M, Miranda HV, et al. a-synuclein interacts with PrP C to induce cognitive impairment through mGluR5 and NMDAR2B. Nat Neurosci. 2017:20(11):1569-79. https://doi.org/10.1038/nn.4648.

44. Quist A, Doudevski I, Lin H, Azimova R, Ng D, Frangione B, et al. Amyloid ion channels: a common structural link for protein-misfolding disease. Proc Natl Acad Sci U S A. 2005;102(30):10427-32. https://doi.org/10.1073/pnas. 0502066102.

45. Danzer KM, Kranich LR, Ruf WP, Cagsal-Getkin O, Winslow AR, Zhu L, et al. Exosomal cell-to-cell transmission of alpha synuclein oligomers. Mol Neurodegener. 2012;7(1):42. https://doi.org/10.1186/1750-1326-7-42.

46. Ehrnthaller C, Ignatius A, Gebhard F, Huber-Lang M. New insights of an old defense system: structure, function, and clinical relevance of the complement system. Mol Med. 2011;17(3-4):317-29. https://doi.org/10.2119/ molmed.2010.00149.

47. Lo MW, Woodruff TM. Complement: bridging the innate and adaptive immune systems in sterile inflammation. J Leukoc Biol. 2020;108(1):339-51. https://doi.org/10.1002/JLB.3MIR0220-270R.

48. Walker DG, Kim SU, McGeer PL. Complement and cytokine gene expression in cultured microglial derived from postmortem human brains. J Neurosci Res. 1995:40(4):478-93. https://doi.org/10.1002/jnr.490400407.

49. Hosokawa M, Klegeris A, Maguire J, McGeer PL. Expression of complement messenger RNAs and proteins by human oligodendroglial cells. Glia. 2003; 42(4):417-23. https://doi.org/10.1002/glia.10234.

50. Shen Y, Li R, McGeer EG, McGeer PL. Neuronal expression of mRNAs for complement proteins of the classical pathway in Alzheimer brain. Brain Res. 1997;769(2):391-5. https://doi.org/10.1016/50006-8993(97)00850-0.

51. Klegeris A, McGeer PL. Complement activation by islet amyloid polypeptide (IAPP) and alpha-synuclein 112. Biochem Biophys Res Commun. 2007;357(4): 1096-9. https://doi.org/10.1016/j.bbrc.2007.04.055.

52. Mastellos DC, Ricklin D, Lambris JD. Clinical promise of next-generation complement therapeutics. Nat Rev Drug Discov. 2019;18(9):707-29. https:// doi.org/10.1038/s41573-019-0031-6.

\section{Publisher's Note}

Springer Nature remains neutral with regard to jurisdictional claims in published maps and institutional affiliations.

Ready to submit your research? Choose BMC and benefit from:

- fast, convenient online submission

- thorough peer review by experienced researchers in your field

- rapid publication on acceptance

- support for research data, including large and complex data types

- gold Open Access which fosters wider collaboration and increased citations

- maximum visibility for your research: over $100 \mathrm{M}$ website views per year

At $\mathrm{BMC}$, research is always in progress.

Learn more biomedcentral.com/submissions 